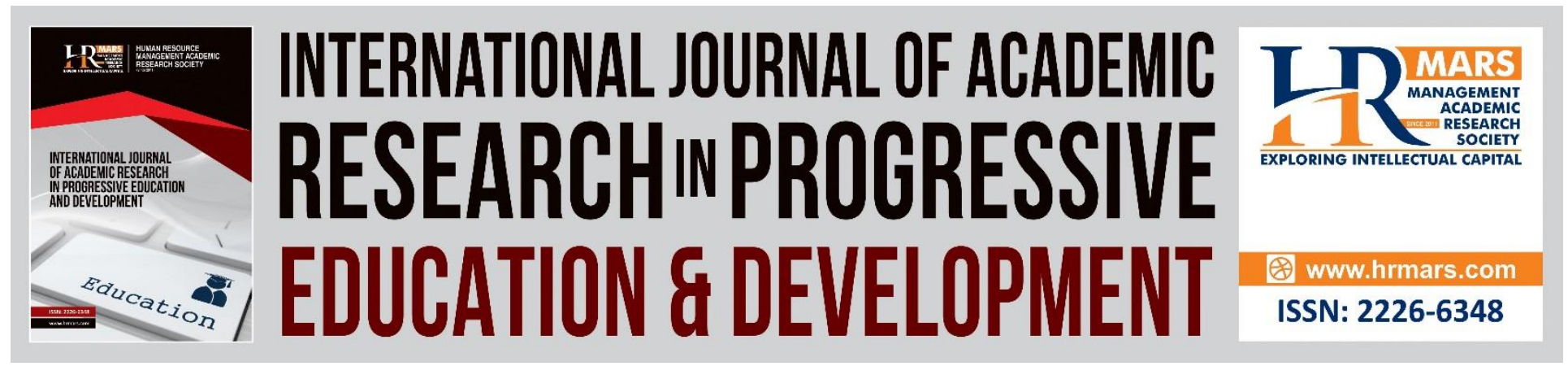

\title{
Innovative Arabic Language Teacher: A Dream or A Hope
}

Rozaini Tukimin, Nik Mohd Rahimi Nik Yusoff, Harun Baharudin, Farihah Hussain

To Link this Article: http://dx.doi.org/10.6007/IJARPED/v7-i4/4844

DOI: $10.6007 /$ IJARPED/v7-i4/4844

Received: 07 Oct 2018, Revised: 29 October 2018, Accepted: 13 Nov 2018

Published Online: 17 Nov 2018

In-Text Citation: (Tukimin, Yusoff, Baharudin, \& Hussain, 2018)

To Cite this Article: Tukimin, R., Yusoff, N. M. R. N., Baharudin, H., \& Hussain, F. (2018). Innovative Arabic Language Teacher: A Dream or A Hope. International Journal of Academic Research in Progressive Education and Development, 7(4), 158-165.

\section{Copyright: (C) 2018 The Author(s)}

Published by Human Resource Management Academic Research Society (www.hrmars.com)

This article is published under the Creative Commons Attribution (CC BY 4.0) license. Anyone may reproduce, distribute, translate and create derivative works of this article (for both commercial and non-commercial purposes), subject to full attribution to the original publication and authors. The full terms of this license may be seen

at: http://creativecommons.org/licences/by/4.0/legalcode

Vol. 7, No. 4, 2018, Pg. 158 - 165

http://hrmars.com/index.php/pages/detail/IJARPED

JOURNAL HOMEPAGE

Full Terms \& Conditions of access and use can be found at http://hrmars.com/index.php/pages/detail/publication-ethics 


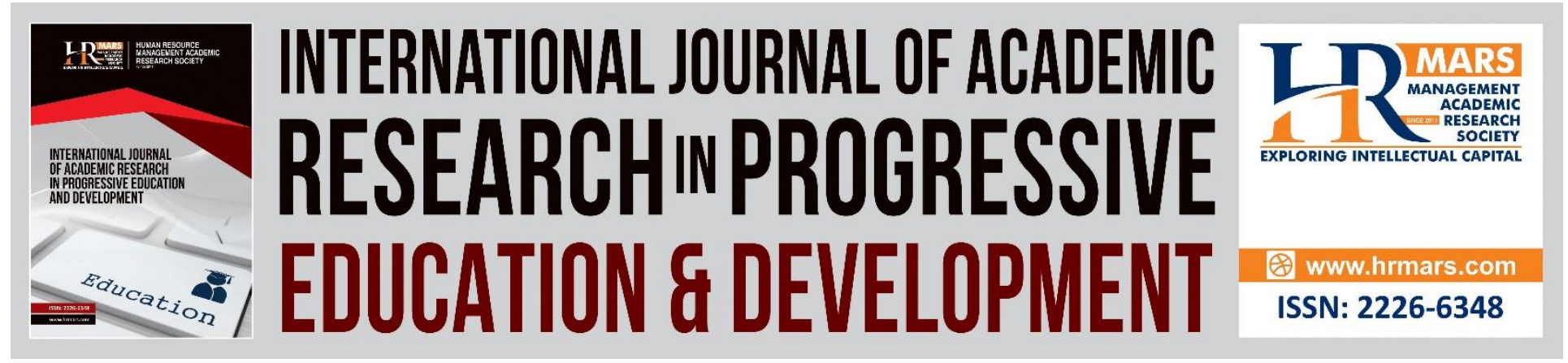

\title{
Innovative Arabic Language Teacher: A Dream or A Hope
}

\section{Rozaini Tukimin*, Nik Mohd Rahimi Nik Yusoff, Harun Baharudin, Farihah Hussain}

Faculty of Education, Universiti Kebangsaan Malaysia 43600 UKM Bangi, Selangor

Malaysia

\begin{abstract}
This article is based on the literature's focus on previous writings and studies by researchers at home and abroad regarding the importance of developing innovative teachers in the education system. This article also discusses the concept of innovative teachers in terms of definition, problem statement related to current situations in teaching, particularly in the field of Arabic language and the division of innovative teacher categories. Further studies are needed to explore the prepping of Arabic language innovative teachers at the school level to serve as a reference and sterling example.
\end{abstract}

Keywords: Innovative Teacher, Innovator, Arabic Education, Innovation, Innovative Teaching Strategy.

\section{Introduction}

Amidst the 21st century, innovation is significant to the ventures of every organization and the field within the country including education. Innovation is the motto, tagline and program in both the government and private institutions. Among them, the theme of Teacher's Day celebration in 2014, "Creativity Trigger Teacher, Innovation Prompter". Whilst this year, in 2017, the theme selected for the Labor Day is "Creative Workers, Innovation Generators". Every year, most organizations will host competitions based on ingenious inventions. It has been proven that innovation is one of the key agenda in the country and is cultivated in various sectors whether in public or private services when Quality Day is replaced by the Innovation Day celebrated on October 31st every year. The cultivation efforts of this innovation culture are under the responsibility of the Malaysian Administrative Modernization and Management Planning Unit (MAMPU) of the Prime Minister's Department (MAMPU, 2010).

Innovation is also a key thrust in government programs and policies such as the Second Thrust of the Five Core Strategies in Malaysia Productivity Blueprint launched by YAB Dato 'Sri Mohd Najib Bin Tun Haji Abdul Razak on 8th May 2017 to prompt digitization and innovation 
Vol. 7, No. 4, 2018, E-ISSN: 2226-6348 @ 2018 HRMARS

(Economic Planning Unit, 2016). Whereas in the Eleventh Malaysia Plan: 2016-2020, its focus is to generate prosperity through innovation and Malaysia's Post 2020 produces innovative citizens (Economic Planning Unit, 2015).

The goal of innovation in public services and non-profit-based institutions is the reduction in operating costs, time-saving, enhancement of work, effectiveness, efficiency and productivity levels, and increased customer satisfaction levels in contrast to profit-based business organizations. In educational policy, innovation is also a major agenda in achieving Student Aspiration through the Malaysia Education Blueprint 2013-2025, the government aims to foster creative and innovative thinking among every students so that they can innovate, generate new possibilities, and create ideas or new and improved knowledge (Ministry of Education, 2013). Based on that, teachers need to employ knowledge on subject matter, teaching and learning, technology to facilitate learning, creativity, and early learning experiences, applying innovation in face-to-face interactions and virtual environments with students.

In this century, the role of teachers is very important despite various fields and departments as they all act as role models in realizing the Student Aspiration which is the agenda of the Malaysian Education Development Plan (PPPM 2013-2025) to build creative and innovative generations. Hence, teachers need to prepare themselves with various skills including applying creativity and innovation in their teachings to deal with new age students (Roslee Talip, 2012).

Teachers who teach Arabic language are also not excluded by this responsibility as they need to implement similar activities in their teachings. Although Arabic has been introduced as one of the subjects of the national education system in the past decades, the level of achievement of the language skills and proficiency is still a problem of various parties at all levels (Mohd \& Nik, 2008; Zainur Rijal Abdul Razak \& Rosni Samah, 2006; Kamarul Shukri Mat Teh, 2008). The weakness of the pupils in the dexterity of Arabic language is much related to the weaknesses of the teachings of the teacher either in terms of approach or material use (Maimun Aqsha, 1991; Noraini, 2010; Noh, 2013; Kamarul Azmi, 2010; Jasmi \& Tamuri, 2011; Mohd Fadzli, 2012; Norhayati, 2014). In that regard, it becomes a requirement for teachers to be innovative and applying innovative strategies in their teaching.

\section{Literature Review}

Each teacher, especially teachers who teach Arabic language, needs to develop their potential as innovative teachers who are able to innovate and reduce the dependency on existing supplies in the commercial market that can ensure the effectiveness of students' achievements. Teachers should make innovation a practice and apply them in their teaching approaches as teachers know better and understand the best approaches and ways to overcome the problem of students with various life backgrounds and various cognitive levels.

\section{Definition of Innovation}

The term innovation was introduced for the first time by world economist and a Nobel prize winner from Austria, Joseph Schumpeter which obtain the name "Prophet of Innovation" in the title of a book (Thomas K. McCraw, 2007). The word innovation comes from the Latin word and 

DEVELOPMENT

Vol. 7, No. 4, 2018, E-ISSN: 2226-6348 ๑ 2018 HRMARS

originally, this word means renewal. Based on the Kamus Dewan (1991), innovation also means renewal. Some scholars provide a variety of definitions; among them are successful creation, development and introduction to new products, processes or new services (Udwadia, 1990).

Innovation is also said to be a dynamic process that requires the input of creativity to produce new ideas or existing assimilation into a new way with the emphasis to create something better (Majaro, 1992). Based on the above definition, it can be concluded that innovation is an element of renewal from the creation of some ideas which is not necessarily be original but must be new to the user, context or application. It includes the reconstruction, impersonation of new ideas and technologies for an organization, followed by developments and implementations (Rozihan, 2002). In the field of service including educational services, innovation is defined as new ideas in all aspects of the work to produce quality services.

\section{Innovations and Teachers}

There are two categories of teachers in terms of innovation. The first category is innovative teacher or innovator. This group is an active innovation agent. They not only accept innovation as a practice but even create a new idea from it. The second category is also accustomed as an adopter. Adopter teacher is a passive agent of innovation. They continue to innovate in teaching according to guidance (McLaughlin, 1993; Fullan, M. \& Miles, M, 1992).

\section{Definition of Innovative Teachers}

Some definitions have been suggested by scholars. Among them, Don Wettrick (2014) defines innovative teachers as teachers using spirit-based teaching and open source to improve their student education. While Judi Randi and Lynn Corno (1997) explain that innovative teachers are pursuing innovative teaching and learning models and present them in the form of ideas, techniques, new teaching aids to practice in teaching and learning. The Innovative Teachers' Award Committee, Ministry of Education Malaysia, provides a more refined and detailed manifestation. Innovative teachers are defined as teachers who can produce innovations in terms of materials, methods, strategies and so forth to improve the effectiveness of learning and teaching processes. Even innovative teachers are teachers who can produce original innovations or improvements to existing ones that include renewal activities and positive changes in learning and teaching processes. Innovative teachers are also regarded as the national curriculum translator into the process of teaching and learning practically (AGI 2018, BPK KPM).

\section{Current Issues in Teaching Arabic Language}

Mastery of Arabic among pupils is still weak (Kamarul Shukri, 2008; Mohamad Azrien, 2010; Rosni, 2012). Teachers are the key element in the effectiveness of learning and teaching besides students and classrooms (M.J Dunkin \& Bruce Biddle, 1974). However, the problem of students' weakness in the mastery of these subjects is often associated with the lack of teacher teachings. Some findings find that most Arabic teachers are still confined to conventional and teachercentered teaching approaches (Mohd Fadzli, 2012; Rosni, 2012; Habibah, 2016).

Similarly, the use of auxiliary materials based on student-centered teaching approaches and materials-based teaching rather than the use of teacher-centered approaches that are still 
DEVELOPMENT

Vol. 7, No. 4, 2018, E-ISSN: 2226-6348 @ 2018 HRMARS

low (Kamarul Azmi, 2010; Rosni, 2012). It has even been found that most Arabic teachers still lack in the latest and less creative and innovative teaching approaches (Kamarul Azmi, 2010). Hence, teachers are required to be creative and innovative.

Fatimah (2010) found that most Arabic language teachers are solely consumers while the auxiliary and teaching materials in the commercial market are less likely to meet the curriculum and student level (Tomlison, 2001). In this regard, Arabic language teachers should be innovators capable of translating the national curriculum into teaching to ensure the enhancement of students' achievement in learning this second language.

\section{The Importance of Innovative Teachers}

Abd Razak (2014) states that teachers play a very important role in applying elements of innovation among students through teaching and learning practices in the classroom. Innovative teachers can encourage and train students to be creative and innovative human beings through imitation of teachers' teaching (Sullivan, 1989; Randi, 1996). Moreover, teachers are often designated as key factors for students (Bolin, 1987).

In addition, it is found that innovative teachers can affect students' motivation (Bolkan, 2009). According to Arbaa (2010), innovative teachers can increase students' interest in learning and teaching. Even, the quality of teaching and learning practices can also be improved (Fullan Bennett, 1990; Lieberman \& Miller, 1986).

Innovative teachers are associated with improved achievements and performances. Abd Razak (2014) in his writings found that innovative teachers can improve their students' achievement and contribute in improving school performance (Hassan, 1995). Innovative teachers are also role models and examples. As a role model, teachers need to be fully versatile in both theoretical knowledge and application of creativity and innovation to meet the challenges of the 21st Century learners. Innovative teachers also act as the primary catalyst who can realize the transformation in education. Along with the Transformation era in education in conjunction with the idea of School Transformation (TS 2025) and National Transformation (TN 2050), teachers are widely cited as the engine of transformation and innovation in the curriculum (Talip, 2012).

Hasan (2002) described innovative teachers as a problem solver that changes the problems faced by the opportunities. Additionally, brainstorming ideas to improve the delivery in solving student's problem in understanding lessons implemented by educators themselves are believed to reduce costs in educational services. Olson (1980) supports his view that the need for innovation is essential from teachers to teachers. This is because the development of innovation from the outside often does not coincide with the curriculum, teacher thinking and student level.

From the aspect of personality, it is found that innovative teachers are effective, excellent teachers and have good attitudes in terms of their own efficacy and confidence. This good attitude will definitely be an example for a student's future. 


\section{Conclusion}

Innovative teachers make a huge contribution to the improvement of students' achievement and the performance of the school. Although the study of innovative teachers or teachers innovators and their teaching practices in the classroom is still lacking and inadequate. In fact, empirical studies have not been specifically identified regarding innovative teachers, but many studies have proven innovative teaching strategies or the use of innovative materials in teaching and learning can improve students' achievement and teacher quality.

A more in-depth study like case study needs to be explored to review an innovative teacher group from a convention perspective. Hopefully, the practice and culture of innovation can be encouraged among public sector workers, especially Arabic language teachers to promote the growth of innovation and the improvement of the quality of educational services.

\section{Corresponding Author}

Rozaini binti Tukimin, Faculty of Education, Universiti Kebangsaan Malaysia 43600 UKM Bangi, Selangor, P90454@siswa.ukm.edu.my.

\section{References}

Razak, A. (2014), Tahap Amalan Inovasi Pengajaran Dan Pembelajaran Dalam Kalangan Guru Sekolah Agama Daerah Kuala Langat, Selangor. Retrieved on 31st of July 2018 http://www.ipgkik.com/v2/wp-content/uploads/2015/05/Artikel17_2014.pdf

Ahmad, S. F., \& Tamuri, A. H. (2010). Persepsi guru terhadap penggunaan bahan bantu mengajar berasaskan teknologi multimedia dalam pengajaran j-QAF. Journal of Islamic and Arabic Education, 2(2), 53-64.

Arbaa, R., Jamil, H., \& Razak, N. A. (2010). Hubungan guru-pelajar dan kaitannya dengan komitmen belajar pelajar: Adakah guru berkualiti menghasilkan perbezaan pembelajaran antara jantina pelajar. Jurnal Pendidikan Malaysia, 35(2), 61-69.

Bolin, F. S. (1987). The teacher as curriculum decision maker. In F. S. Bolin \& 1. Falk (Eds.), Teacher renewal: Professional issues, personal choices (pp. 92-108). New York: Teachers College Press.

Bolkan, S., \& Goodboy, A. K. (2009). Transformational leadership in the classroom: Fostering student learning, student participation, and teacher credibility. Journal of Instructional Psychology, 36(4), 296.

Dewan, K. (1991). Edisi Ke-4, Dewan Bahasa dan Pustaka. Kuala Lumpur.

Dunkin, M. J., \& Biddle, B. J. (1974). The study of teaching. Holt, Rinehart \& Winston.

Economic Planning Unit. (2015). Eleventh Malaysia Plan 2016-2020. Prime Minister's Department.

Economic Planning Unit. (2016). Malaysia Productivity Blueprint: Driving Productivity of the Nation. Prime Minister's Department.

Fullan, M. \& Miles, M. (1992). Getting reform right: What works and what doesn't. Phi Delta Kappan, 73(10),745-752.

Fullan, M., Bennett, B, \& Rolheiser-Bennett, C. (1990). Linking classroom and school improvement. Educational Leadership, 47(8), 13-19. 
INTERNATIONAL JOURNAL OF ACADEMIC RESEARCH IN PROGRESSIVE EDUCATION AND DEVELOPMENT

Vol. 7, No. 4, 2018, E-ISSN: 2226-6348 @ 2018 HRMARS

Habibah, M. R. (2016). Amalan pentaksiran dalam pengajaran dan pembelajaran INSYA'sijil tinggi agama Malaysia (STAM)/Habibah Mat Rejab (Doctoral dissertation, University of Malaya).

Jasmi, K. A. (2010). Guru cemerlang pendidikan Islam sekolah menengah di Malaysia: satu kajian kes (Doctoral dissertation, Universiti Kebangsaan Malaysia).

Jasmi, K. A., \& Tamuri, A. H. (2011). Amalan Penggunaan Bahan Bantu Mengajar dalam Kalangan Guru Cemerlang Pendidikan Islam Sekolah Menengah di Malaysia, 3(1), 59-74.

Lieberman, A. \& Miller, L. (1986). School improvement: Themes and variations. In A. Lieberman (Ed.), Rethinking school improvement (pp. 96-111). New York: Teachers College Press.

Majaro, S. (1992). Managing ideas for profit: The creative gap. McGraw-Hill.

MAMPU. (2010). Panduan Peningkatan Budaya Inovasi Dalam Perkhidmatan Awam. Jabatan Perdana Menteri.

McCraw, T. K. (2009). Prophet of innovation. Harvard University Press.

McLaughlin, M. W. \& Talbert, 1. E. (1993). Contexts that matter for teaching and learning. Stanford: Center for Research on the Context of Secondary Teaching.

Ministry of Education. (2013). Malaysia Education Blueprint 2013 - 2025. Putrajaya.

Tukimin, R., Yusoff, N. M. R. N., Baharudin, H., \& Hussain, F. (2018). Innovative Arabic Language Teacher: A Dream or A Hope. International Journal of Academic Research in Progressive Education and Development, 7(4), 158-165. 